Journal of the Society for the Study of Architecture in Canada Le Journal de la Société pour l'étude de l'architecture au Canada

\title{
A Contested Carpet
}

Portrayals and Metaphors of Gender on the Suburban and

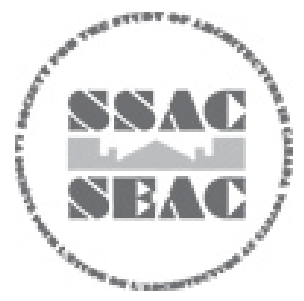

Estate Lawns in Canadian Homes \& Gardens, 1925-1935

\section{Stephanie Weber}

Volume 44, numéro 2, 2019

URI : https://id.erudit.org/iderudit/1069483ar

DOI : https://doi.org/10.7202/1069483ar

Aller au sommaire du numéro

Éditeur(s)

SSAC-SEAC

ISSN

2563-8696 (numérique)

Découvrir la revue

Citer cet article

Weber, S. (2019). A Contested Carpet: Portrayals and Metaphors of Gender on the Suburban and Estate Lawns in Canadian Homes \& Gardens, 1925-1935. Journal of the Society for the Study of Architecture in Canada / Le Journal de la Société pour l'étude de l'architecture au Canada, 44(2), 41-55.

https://doi.org/10.7202/1069483ar d'utilisation que vous pouvez consulter en ligne. 


\section{A CONTESTED CARPET: Portrayals and Metaphors of Gender on the Suburban and Estate Lawns in Canadian Homes \& Gardens, 1925-1935}

STEPHANIE WEBER will graduate in spring

2020 with an M.A. in art history from Concordia

University in Montreal. Her research focuses on

the built environments and material histories of Victorian and interwar Canada. She holds a B.A [Honours] in history and English literature from Mount Royal University in Calgary.

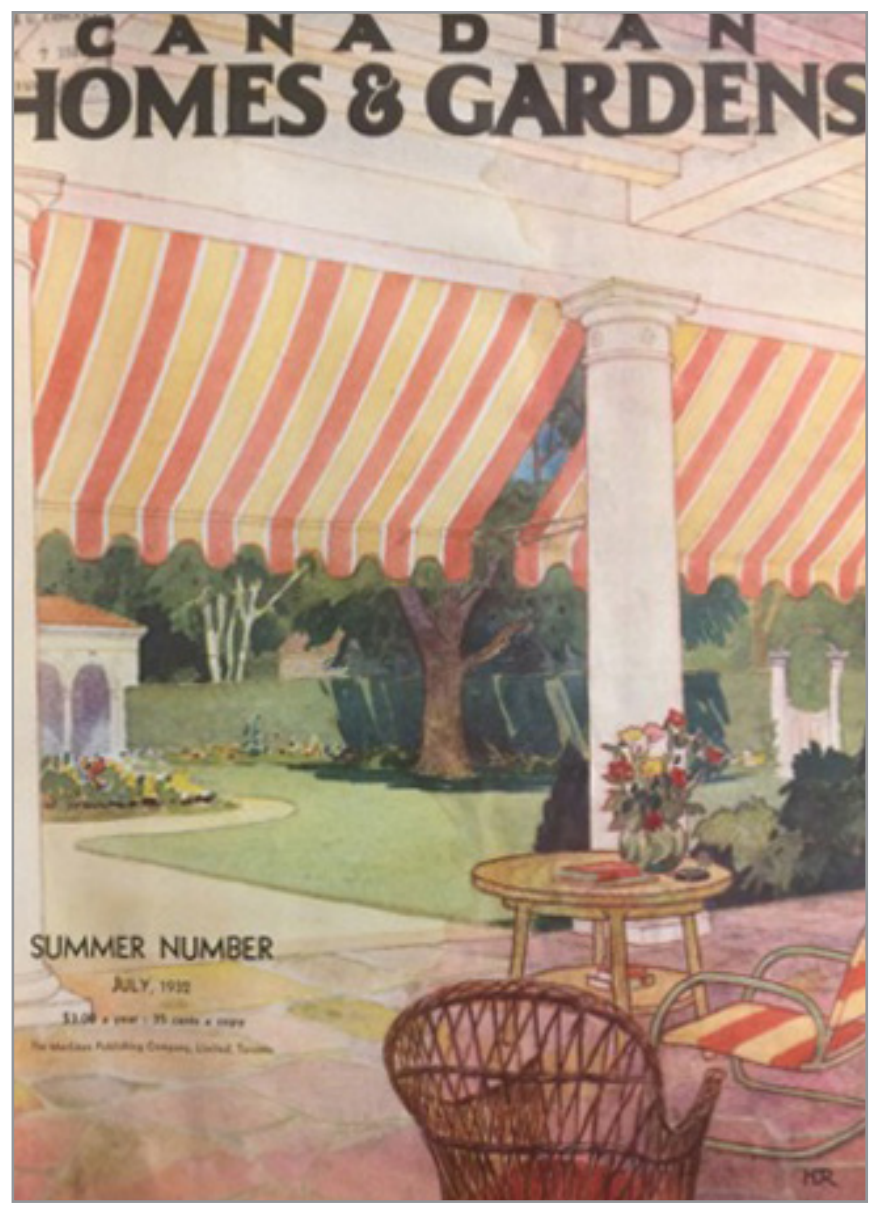

FIG. 1. COVER IMAGE, JULY 1931 | CANADIAN HOMES \& GARDENS

\section{$>$ STEPhANIE WeBER}

In the cover image of the 1931 "Summer Number" of Canadian Homes \& Gardens, a variegated cobblestone terrace opens onto a bright green lawn, the grass framed grandly by tall white columns and a vividly striped awning (fig. 1). The space of the lawn is demarcated by a tall hedge, which is interrupted only by a distant gazebo and an elegant white gate, while part of the grass is thrown into shadow by the dense foliage of a large tree. On the terrace, two chairs are settled about a table upon which sit books and an ashtray, while throughout are floral accents-both planted along a pathway and arranged in a tabletop vase. A detailed illustration of an exterior space is created, with a patch of blue sky visible between the gap of the brightly coloured awning - but its exteriority is complicated by the details that suggest it is contiguous with the interior of a house: a solid roof, the clear boundary of the hedge separating the lawn from public space, and the presence of cushioned seating and drawing room details. Certainly, the contemporary styles of the wicker and aluminum furniture, the well-groomed character of the grass itself, and the hinted grandeur of the surrounding architecture indicate that this space was desirably styled and landscaped. The idealized outdoor space, here, is domesticized-the leisure activity of reading is moved outdoors, suggesting that so too has the living room been moved outside for the season, but the hint of blue sky in the gap between two awnings suggests the importance of its location outdoors. This illustration is typical of graphics both on the covers and throughout the interiors of issues of the magazine-taken together, these images 
point to a dense cultural mythology surrounding the characterization of the role that the lawn of an upper-middle-class or elite Canadian estate could or should play. By examining pictures such as this one, as featured throughout the publication over its years in print, we can come to understand how its Canadian readers might have come to understand the space of the lawn as mythologized through the discourse of the magazine. Implicit in this mythology are the gendered connotations of the interior and exterior, expressed in the labour associated with these spaces, the aesthetic coding of their decoration, and those who were assumed to inhabit each space.

Canadian Homes \& Gardens was a monthly domestic design and lifestyle magazine first published in 1925 by W. Rupert Davies and soon after purchased by the MacLean Publishing Company. It contains a visual archive of affluent Canadian homes, as well as advice for readers about the items and equipment they should buy to create a well-curated home and garden. ${ }^{1}$ In print from 1925 until 1962, the magazine was marketed to an upperclass readership, listing luxury products for sale and profiling estate homes, usually located in Montreal, Toronto, Vancouver, or Victoria. The magazine's readership would have resided increasingly in the suburbs, as it was primarily affluent families, before the housing boom in the 1950s, that had the flexibility and financial resources to live so far from city centres. ${ }^{2}$ The publication was one of the several Canadian "women's magazines" in print in the twentieth century to provide content for Canadians not sourced from American competitors, and thus was one of the few interwar examples of specifically Canadian home design magazines, along with Canadian Home Journal. Canadian Homes \& Gardens also often purported to pinpoint a particular
Canadian aesthetic, one unique to the country that attempted to define its national identity through providing idealized versions and advice on the proper aesthetics of the Dominion's domestic space. ${ }^{3}$ Its contents, then, should be understood in part as contributions to a visual culture around the ideal home, the distribution and appearance of domestic space, and the gendered assumptions implicit in these myths.

In order to understand the ways in which magazine images can exercise such discursive power, this essay will draw from Roland Barthes's essays on semiotics. In Barthes's understanding, language as well as images function as "signs" on one level, denoting their literal primary meanings, but further, as "myths." It is these myths that this essay seeks to demystify; as the image of the lawn proliferated and became a desirable object portrayed in these publications, it also came to signify a kind of performative nationalism tied to the ideal family and to gendered articulations of those family roles. Valerie Korinek's Roughing it in the Suburbs (2000), an influential work of Canadian history considering the magazine Chatelaine, lends to this essay a lens through which one might understand the way the audience of women's magazines could understand the images they saw. Korinek is sure to acknowledge the agency of the women readers, who could take pleasure in this kind of reading and were not necessarily passive consumers of the content they enjoyed. ${ }^{4}$ Additionally, it is historically clear that while house and garden magazines of the twentieth century were generally written for women, it is not sufficient to assume that women made up their only readership. ${ }^{5}$ Thus, constructed myth did not necessarily enjoy an uncomplicated path from creator to unquestioning consumer. While acknowledging that, this essay is primarily concerned with the construction of these rich landscapes of myth themselves, as, whether or not they were universally convincing, the traction of these ideas is clear, especially as the century progressed. I surveyed one hundred issues spanning the first ten years of the publication, taking stock of images of lawns, articles directly related to or mentioning lawns and lawncare, and advertisements for a variety of lawncare products. Taken together, these images may be understood as a variety of contributions to an occasionally contradictory mythology of gendered space and the Canadian lawn.

One of the most iconic signifiers of domesticity in twentieth-century America remains the lush, green, and precisely maintained suburban lawn. The image of this lawn has come to visually dominate much of American popular culture, serving as a symbol of generic suburbia and, further, as a kind of reinforcement of the ideal financial security and domesticity that still defines the archetypal American Dream. As architect and historian Mark Wigley has suggested, the sheer dominance of images featuring happy families perched upon perfect, green grass has come to reinforce an association between the "well-maintained lawn and the wellmaintained family." ${ }^{6}$ Importantly, these concepts are implicitly tied to gender, and through investigating the ways that lawn space was configured and discussed, its very ambiguity can cast light on conflicting visions of ideal gender performance, acceptable gendered space, and the place of women during the interwar period. While, perhaps, suburban lawns are most closely associated with the postwar "cult" of domesticity, many of the idyllic green lawn images associated primarily with the 1950s and 1960s were strongly articulated during the intermittent prosperity and desolation of the interwar period. The 
decades between the world wars constituted a period of great economic and social anxiety, so idealized imagery represents not only a romanticized notion of what people might have striven for, but also an unreachable ideal available only to a select few.

In Canada, a nation that has been inundated by the cultural production of the United States for the better part of its history, this image of the cheerful family on a healthy lawn is similarly salient. Canada's position as both a former colony still under strong loyalist imperial alliance with Britain and neighbour to the cultural juggernaut of the United States further complicates these ambiguities as both countries influenced the way that the lawns in the Dominion were articulated and perceived. The green spaces surrounding Canada's nineteenth-century villas, for example, were often cultivated in a "French" or "British" manner, depending on the pedigree of the homeowner. ${ }^{7}$ Furthermore, American influence on Canadian home design was increasing at the beginning of the nineteenth century. ${ }^{8}$ These competing influences, and Canada's position as a nation contending with what much of its cultural output portrayed as a hostile wilderness, made the interwar Canadian lawn a particularly rich site indicative of a host of cultural anxieties, competing values, and technological developments. Additionally, the interwar period was fraught with economic and social tension, and as the lawn is symbolically loaded with gendered imagery, it is worth considering in the context of a nation that had recently granted women the vote in 1918 and only declared women "persons" in 1929 amidst a nationwide debate. The aesthetic and social space of the lawn may be taken as one site of anxiety around the changing role of women during that period of coincident liberation and repression.
Accessing the rich archive of imagery surrounding the lawn in order to suggest the mythology developed around gendered ideals can reveal much about the narratives presented to Canadians about gender and domestic space; an often contradictory message that both distorts and reveals the ways in which gendered experience was in flux.

\section{DOMESTICITY IN PRINT}

The ubiquitous image that Wigley identified-that of the happy nuclear family upon their suburban lawn-proliferates in the pages of Canadian Homes \& Gardens throughout the 1920s and 1930s. This image of the idyllic and normative turf lawn can be traced to a range of possible roots throughout Western culture. In the late 1970s, the American geographer Pierce $F$. Lewis suggested a now widespread set of "axioms" that function as a series of guidelines for historians to "read" the cultural meanings of human landscapes. ${ }^{9}$ The first, "the axiom of landscape as clue to culture," suggests that landscapes "provide strong evidence of the kind of people we are, and were, and are in the process of becoming." 10 Another, "the historic axiom," suggests simply that "things we do are inherited from the past."11 Utilizing these two points as a guideline, we might "read" the lawns that increasingly proliferated across Canada's suburban landscapes in the interwar period. Manmade landscapes that featured turf may be traced to British landscape traditions. One notable instance of the venerating of sweeping green landscapes are the idealized panoramas of late eighteenth- and early nineteenth-century romanticism, which often featured "flat expanses of lawn" and other greenery planted "with an eye to what was attractive."12 This treatment of the landscape was advocated by such figures as Lancelot "Capability" Brown and Humphry Repton, who resisted formalized convention in favour of designed landscapes which appeared to leave the environment unaltered..$^{13}$ Picturesque ideals held that landscapes should be framed-views were meticulously designed by landscape architects but in a style that appeared as though it might have been "natural"—and "vistas" were created, meant to be viewed through windows or from gazebos.

Urban historian Kenneth T. Jackson has noted that while the concept of the "suburb" predates the Enlightenment, suburbanization-the process by which fringe areas grew rapidly and systematically in larger proportion to core citieswas a later trend, beginning in Britain and North America around 1815. ${ }^{14}$ Twentiethcentury suburbanization, Jackson suggests, was a geographic manifestation of some of the cultural features that rose in North America alongside it; namely, "conspicuous consumption, a reliance upon the private automobile, upward mobility, the separation of the family into nuclear units, the widening division between work and leisure, and a tendency toward racial and economic exclusiveness." 15

It was this pattern of suburbanization toward which Canadian Homes \& Gardens was oriented-the wide adoption of automobiles among the upper class contributed to the greater accessibility of homes further from the city centre, provoking a turn to suburban domesticity that predated that of the middle of the century (car advertisements are numerous throughout the publication). Pages of real estate listings in the magazine featured large estates and suburban homes, with only a minority of addresses in the inner city. Even those inner city addresses sought to emulate suburban homes in the interwar period, moving further back on their lots to allow for ample front lawn 
space. ${ }^{16}$ The advertisements in Canadian Homes \& Gardens generally assumed a suburban audience and even geared their contents toward the necessities or anxieties of the suburban homeowner: a 1926 advertisement for a fire retardant called Pyrene, for example, is headed with the tagline "we live in the suburbs" and a photograph of a house upon a suburban lawn, calling to audiences of the magazine whose "beautiful homes," removed from the resources of the inner city, might benefit from the protection guaranteed by the product. ${ }^{17}$

Within each 100-page issue of Canadian Homes \& Gardens, about ten of those pages toward the front of the magazine are devoted to profiles of distinctive Canadian homes, with article-length features on the design choices involved in their construction and decoration accompanying full-page, black-andwhite photographs. These images depict both the interiors and exteriors of each home, while accompanying articles include information about the owners, who were often dignitaries or members of the Canadian government, as well as, frequently, suggestions and inspiration drawn from these homes for readers' own gardening and domestic decorating. The homes featured in this way always possess front lawns, suggesting the established ubiquity of turf grass on estates as well as on smaller lots. Also in the first half of the magazine are featured homes of a more modest range, though these too are usually still relatively large and stately. Profiles on these homes, which, in some issues, are represented by sketches, and in others by photographs, are usually accompanied by their architectural and garden plans. These, as is suggested by the pragmatic inclusion of documents enabling readers to see precise design choices, were more directly meant to advise readers on how to plan and decorate their home and garden. In home features, lawns either frame the homes, or the spotlight is put on the way that the view from the home frames the lawn. In both cases, the importance of the "picturesque" is clear, as lawns are represented as a feature of beauty that can either enhance the appearance of a home from the street or function as a pleasant vista to experience from within domestic space.

The association of nuclear family units with ideal domestic Canadian life, and thus upon lawns, was also reified in Canadian Homes \& Gardens. Illustrations of smiling nuclear families proliferate throughout the magazine. A 1931 McLaughlin-Buick advertisement illustrates a smiling uniformed chauffeur telling a child "your dad knows cars" as the two sit in the driver's seat of an automobile. Behind them, visible from the car window, is the door of a house at the end of a pathway through a green front lawn, suggesting a scene of domesticity from which the child hails-one clearly coded by class status, considering the presence of an employed driver (fig. 2). This advertisement seems to be targeted toward a male automobile buyer-one who could attain a certain appropriately masculine knowledge of vehicles by making rational consumer decisions. It would thus be this man's landscaped front yard that appears in the background, another signifier of idealized class status and domestic propriety. Additionally, advertisements for food, though rare in the magazine, usually depict familial scenes as well: a 1935 advertisement for Chateau Cheese shows a white nuclear family picnicking atop some grass. This image associates their location with adventure and leisure by its suggestion that families take the cheese on "motor trips" or "fishing jaunts." 18 Grass, here, provides an association with fitness and health, and is the backdrop for a scene of family togetherness. In a 1932

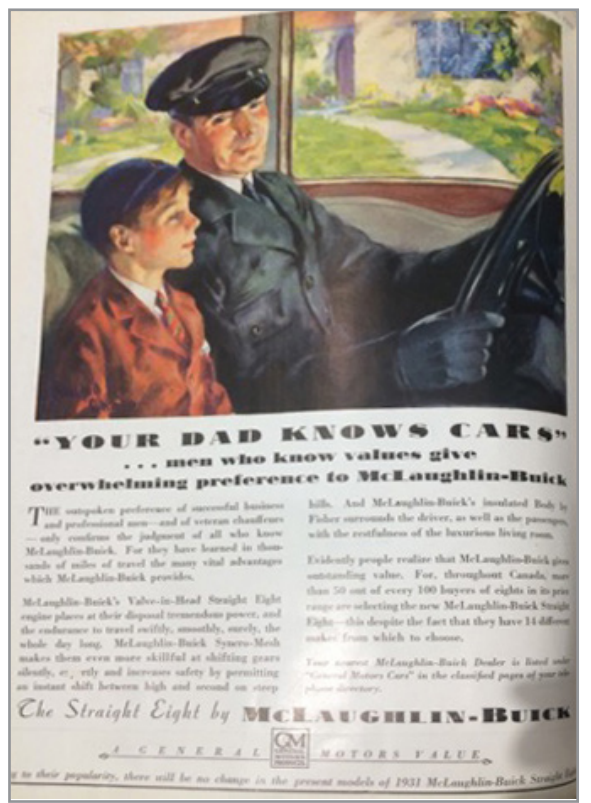

FIG. 2. "YOUR DAD KNOWS CARS," INSIDE COVER, AUGUST 1931 | CANADIAN HOMES \& GARDENS

advertisement for the Cine-Kodak home movie camera, a cheerful white couple captures an image of their smiling baby standing beside a tree, with feet planted in surrounding grass. ${ }^{19}$ Common among these advertisements is the depiction of heterosexual, nuclear family units, and the whiteness of those families. The suburban condition as defined by Jackson is clear here: grass and lawns are visual markers of security and home that extended into public spatial practice for a social paradigm that ordered upper-class North American society.

\section{THE CANADIAN OUTDOORS}

While many of the images present in Canadian sources are almost indistinguishable from those in American sources, some theorists suggest that specific aesthetic movements, as well as ideological attitudes toward landscape, distinguish the Canadian lawn from the American lawn. In both countries, lawns and the suburban paradigm proliferated 


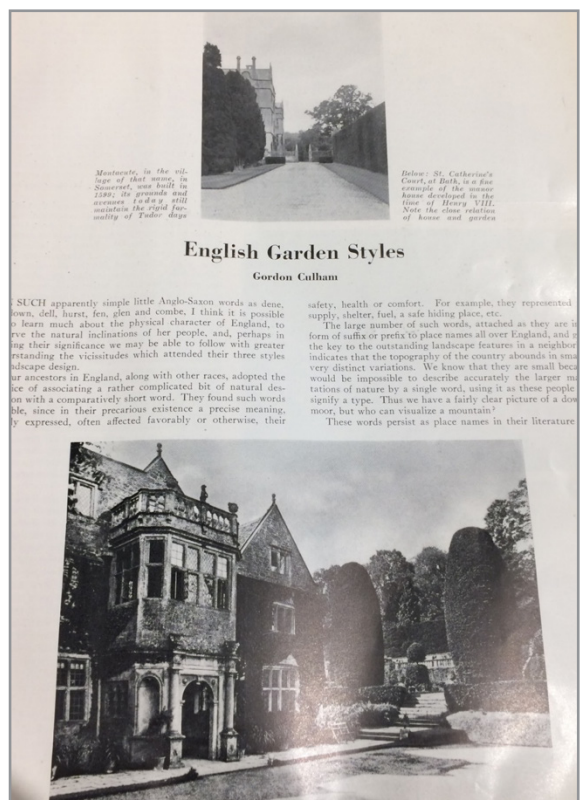

FIG. 3. "ENGLISH GARDEN STYLES," JULY 1930, P.39 | CANADIAN HOMES \& GARDENS

in similar patterns throughout the nineteenth century. The Canadian literature historian Shelley Boyd, however, notes that English traditions defined many Canadian home gardens and lawns, especially the romantic fashion of having greenspace appear unaltered from its natural state. ${ }^{20}$ Though these traditions had generally gone out of style in the United States by the 1820 s, the landscapes of English romanticism remained popular in Canada, in part, as historian Cayley Bower has suggested, because post-Confederation Canada, eager to express ideas of progress and nationalism, used the traditions to emphasize "the primacy of emotional experience" and the "centrality of the individual." 21 Indeed, many of the gardens featured in Canadian Homes \& Gardens are described in terms of what they borrow from the British tradition. For example, Gordon Culham notes in the July 1930 issue the gardening practices of "our ancestors in England," including images of historic English homes, and suggesting ways that some of the "truly
English" gardens and terraces might be adapted to the Canadian land (fig. 3). ${ }^{22}$

Theoretical and literary attitudes to the Canadian landscape have also differed from those of other countries because of a nationally reified myth that much of the country is made up of hostile, unconquerable wilderness. Figures such as Margaret Atwood and Northrop Frye have traced the "Garrison Mentality," the idea that Canadians were concerned with survival and pragmatism over the idealism and individualism that characterized the United States. ${ }^{23}$ In the same July 1930 article, Culham suggests that "livableness" is what concerns landscape design in Canada over "display," while other articles note the beauty of "distinctively Canadian" gardens when they are covered in snow. ${ }^{24}$ Advertisements also often emphasize the "extremes" of Canadian weather, such as a 1930 Kenneth McDonald \& Sons Ltd. advertisement for grass seed that assure "fine, dense, velvety turf" able to withstand the "frosts" with its strength. ${ }^{25}$ If Canadians understood their environment as difficult and harsh, the maintenance of the lawn takes on a particular importance as a landscape of control. If a Canadian lawn was well-maintained, this, at least metaphorically, meant that a homeowner had been able to exercise a dominance over that environment in order to cut down wild bush and plant and maintain an orderly square of lush turf.

\section{MORALIZING GREENERY}

In many profiles on distinctive homes, authors would assume a moralizing tone, especially when describing both the benefits of greenspace and outdoor space of leisure activity, as well as when describing the labour that went into cultivating these spaces. In part, this moralizing tradition drew from the romantic movement. Lawns, the Canadian social historian Peter Ward points out, have little utility unless "we include a sense of oneness with nature." 26 This sense of connectedness to the natural was exactly the quality of green space often praised in Canadian Homes \& Gardens. An image in a feature published in July 1931 purports the benefits of homes away from the city centre and all its "limitations," open to "men of position and means" to give their families "room to breathe and play." 27 The sociologist Lewis Mumford, who generally condemned suburbs, suggested in 1921 that lawns could be effective to "exercise control over the excessive energy of youth." ${ }^{28}$ Echoes of the rhetoric of the "child-saving movement" crucial to social reform, which sought to solve youth criminal behaviour and suffering by providing access to outdoor play spaces, are also present in advertisements for playground equipment. ${ }^{29}$ An advertisement for the Frost "O-Boy" home playground from 1927 appeals to parents to "keep [their] children off the street" and give them "the healthful, body building exercise they crave," "in their own yard." ${ }^{30}$ Lawns, as spaces for childrearing and family raising, were constructed as essential to children's health and moral wellness.

This moralizing was often attached to assumptions of masculinity and virility that took their resonance from the connection between landscaping and physical labour. A feature on a rural farmhouse in an issue from May 1930 argues that "men who are leaders in the affairs of Canada, are turning to the countryside, to gardening and to serious farming," praising this group of "gentleman farmers" and suggesting that any man engaged in this work "must be a compelling influence for good in his community." ${ }^{31}$ Similarly, another article in the same issue points to the phenomenon of business men who "return to the plow," suggesting that this action gives 
men who have been corrupted morally by the city the opportunity to be morally cleansed by an expanse of land and the experience of hearty, physical labour. ${ }^{32}$ Both articles feature photographs of the homes set against wide, flat lawns.

\section{THE LAWN AS AN EXTENSION OF THE HOME}

The use of "separate spheres" ideology, or the understanding that a woman's "place" is indoors or in privacy in a caregiving role, may also be conducive to decoding some of the language around lawns in the magazine. ${ }^{33}$ Lawns are often referred to as though they are part of, linked to, or an extension of the home in articles and advertisements-a 1933 spread, for example, calls the garden "an intimate extension of the house," while an August 1933 article proclaims that the "Garden and House are Intimately Linked." ${ }^{34}$ Lawn furniture advertisements in particular often referred to the lawn as an "outdoor living room," suggesting that, during summer, the lawn could literally function as a physical extension of the home and as an ideal space for family time and leisure..$^{35}$ In an Imperial Rattan Company Ltd. advertisement run from 1933, typical of these outdoor furniture advertisements, an umbrella, four chairs, and two tables are arranged upon a lawn beside the open window and an extended awning on the side of a home's stucco walls (fig. 4). Glassware and tennis rackets are strewn on one table, and another racket is propped against one of the chairs. While no family is present in this advertisement, the impression of domesticity and leisure is suggested by the presence of these objects. If the home is characterized by its capacity to act as a space of leisure and care for men and children, this advertisement provides an image of the outdoors that aligns with this notion. ${ }^{36}$ Similarly, a Robert Simpson

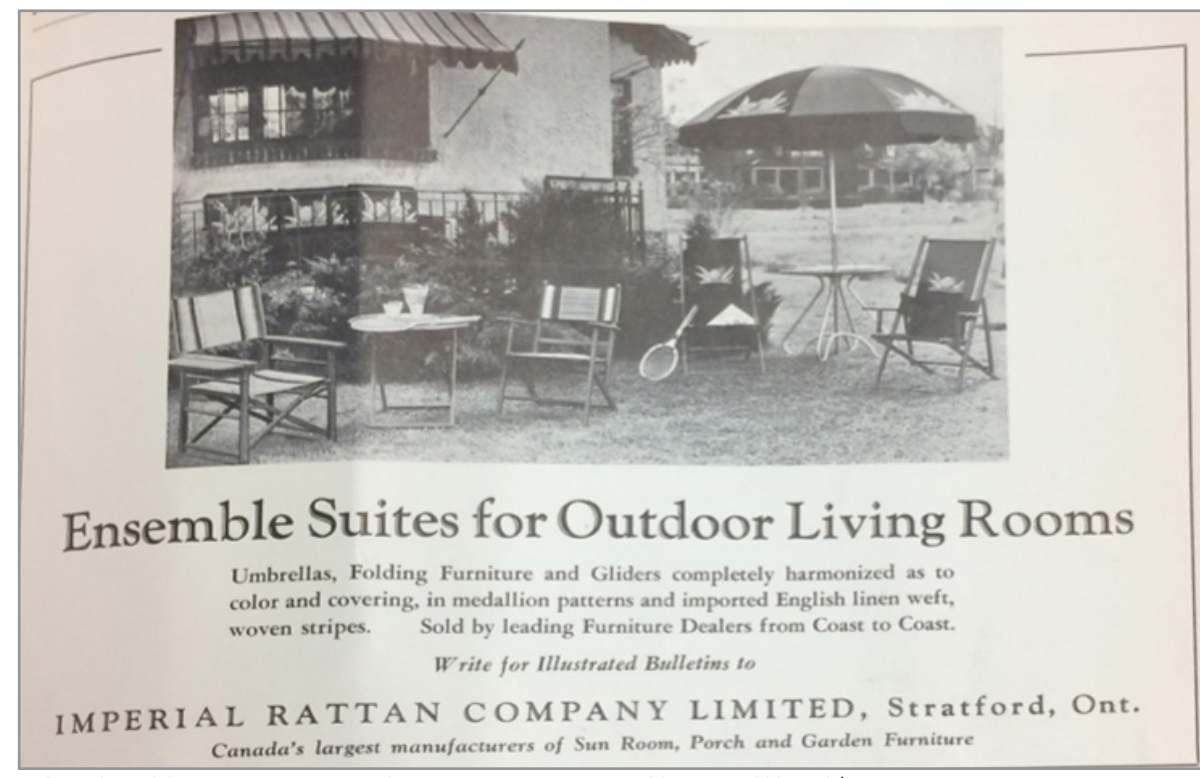

FIG. 4. OUTDOOR FURNITURE ADVERTISEMENT, IMPERIAL RATTAN CO., JUNE 1933, P.49 | CANADIAN HOMES \& GARDENS

advertisement from the 1934 June-July issue displays an image of three lawn chairs and a long striped "Glider Couch" facing a central circular table, featuring a pitcher with five drinking glasses and a large lawn umbrella extending through its centre (fig. 5). The circular shadow cast by this umbrella resembles an area rug, on which the legs of the chairs and couch rest. The advertisement tells consumers to invest in "comfortable, cool, restful furniture" in "dramatic, arresting colors" for their "leisure hours" will occur outside in the summer, "when the family moves to the porch and garden." ${ }^{37}$

Virginia Scott Jenkins suggests that the front lawn was often treated as "an extension of the formal public space of the home," featuring "green velvety carpet" and "cast-iron furniture." 38 Canadian Homes \& Gardens often included guides for hosting parties as well as recipes for guests and would publish specific guides in the summer months for outdoor parties or family meals to be hosted on the lawn. Understanding the front lawn as an extension of the domestic space used for accommodating visitors, we can contextualize some of the ways that lawns appeared in articles that featured pictures of lawn furniture. A 1932 article titled "Garden Settings for Meals" provided a guide for hosting meals outdoors, suggesting that relocating dining outside in summer imparted "delightful zest," pointing to the "weaving of sun and shadow upon the grass." ${ }^{39}$ Several photographs of complete dining rooms within open canopies are set beside this article, illustrating pergolas for taking meals with one or multiple sides open to expansive and landscaped lawns (the pergolas featured in these images are large and lavish, with full dish sets and sets of dining room furniture, and would have been unattainable for the majority of the middle-class readers, but might have appeared emblematic of an ideal standard of prosperity). These types of articles usually included recipes for meals with several courses, as well as additional instructions, such as the ideal amount of shade for the location of each meal. These articles were usually 


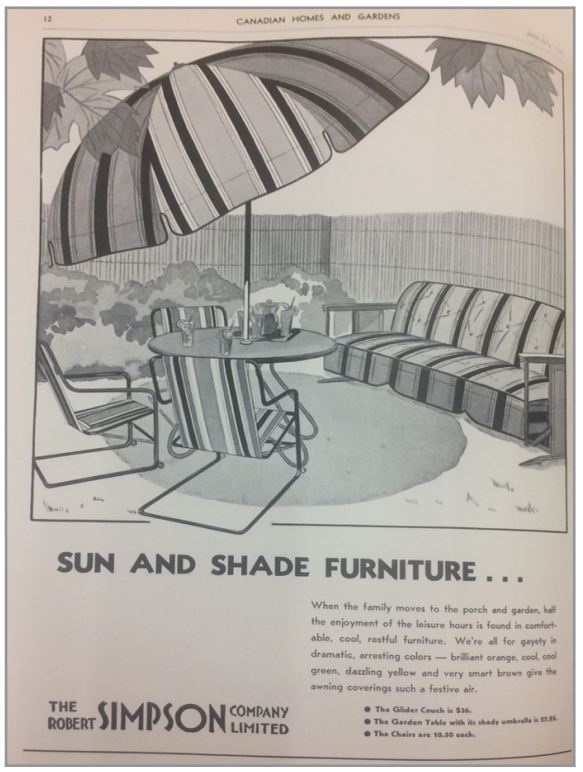

FIG. 5. "SUN AND SHADE FURNITURE..." THE ROBERT SIMPSON COMPANY LIMITED, JUNE-JULY 1934, P.12 | CANADIAN HOMES \& GARDENS

authored by women and often referred to their readers as "ladies" or "mothers."40 By moving the setting for the gendered labour of hospitality and homemaking out of doors, the space of the lawn was made into women's domain along with the kitchen and the dining room.

Much of the language invoked around suburban gardens aligned the lawn with the interior of the house. Alessandra Ponte notes that gardens, and thus the lawns that covered their "floor," were often described "in terms of interior decoration" for women audiences. ${ }^{41}$ Lawns had been described using metaphors of rugs, carpets, or velvet long before the 1920s. However, famed nineteenth-century landscapers such as A.J. Downing and Charles Bridgman frequently invoked the imagery of carpets when suggesting that grass should keep a neat and regular appearance, and Henry Cleaveland, writing on domestic maintenance in 1856, suggested that "a carpet before your house" "will infinitely outlive any you can spread within." 42

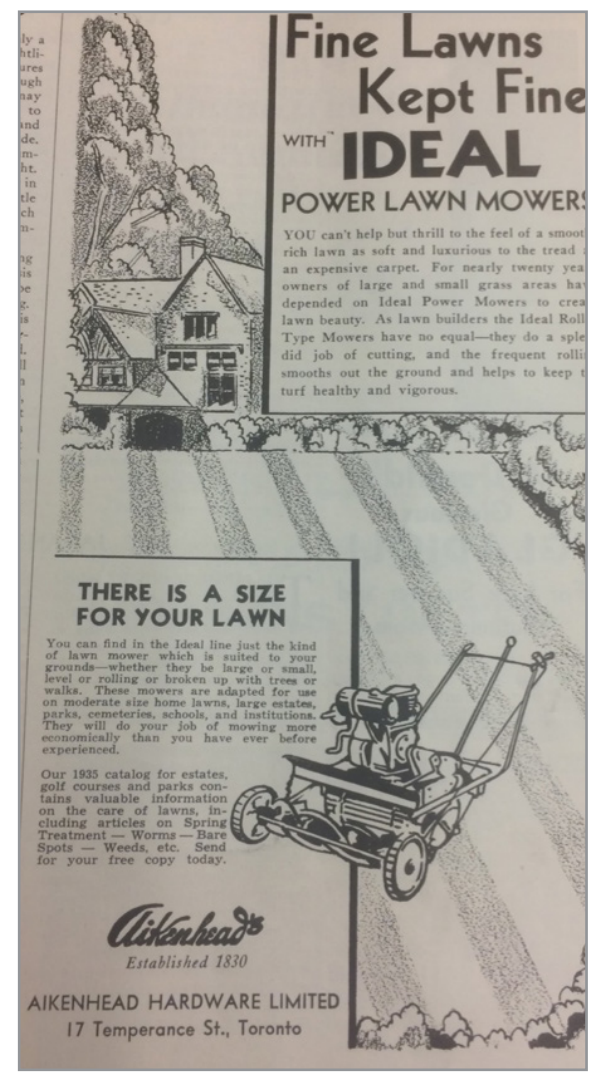

FIG. 6. IDEAL POWER LAWN MOWERS ADVERTISEMENT, MAY 1935, P. 77 | CANADIAN HOMES \& GARDENS

This language is common in a variety of places in Canadian Homes \& Gardens. In advertisements, "carpet-like" is often used as an adjective for the ideal lawn, which could be achieved through the use of mowers or sod. ${ }^{43}$ A 1935 advertisement for Ideal Power Lawn Mowers compared the "feel of a smooth, rich lawn" to the "soft[ness]" and "luxur[y]" of "an expensive carpet," featuring a mower superimposed over an illustration of a just-rolled lawn before a large home (fig. 6). The lawn, here, is uniform and rectangle, and the stripes ostensibly left by mowing it in long, straight lines give it the appearance of an interior rug with a geometric pattern. Further, carpets were a luxury item, and even constituted a status symbol in Europe and North America from the sixteenth century. ${ }^{44}$ An association between a well-cared-for lawn and a carpet was then associated not only with the indoor space but with wealth and taste. ${ }^{45}$

In many ways, however, much of the rhetoric surrounding the cultivation and perfection of lawns was dominated by the fact that lawns were visible to the public eye. In a feature from January 1930, Canadian Homes \& Gardens suggests that cultivating backyards is the "cheapest and quickest" way to "beautify a community." 46 Paired with this feature is an image of a cultivated garden upon a bed of grass appearing to be surrounded by a high hedge, and thus shielded from public view. The purpose of designing an outdoor "appendage," however, according to the accompanying text, is what each lawn lends to the beautification of the larger neighbourhood. An article published in February 1930 that profiles a home in the prestigious Vancouver neighbourhood of Shaughnessy Heights describes the "well-kept" green turf that frames the home at multiple instances: the "emerald turf," suggests the article, "frames" both the house and the flower garden, creating a view of the home to one on the street comparable to a scene of a "petite flower-girl at a grand wedding." ${ }^{47}$ Thus, a clear audience is identified, and readers are encouraged to keep their lawns cultivated for the pleasure of onlookers.

In a 1932 advertisement for Frost Fences, the woman subject in the illustration, speaking with her husband, suggests that their purchase of the fence has doubled their property value. In the text beneath the image of the fence, the woman in the advertisement seems to elaborate to the reader on the "wonderful privacy" and value that her purchase has given her grounds. Alluded to here is a vital issue at play: that of seclusion and private 


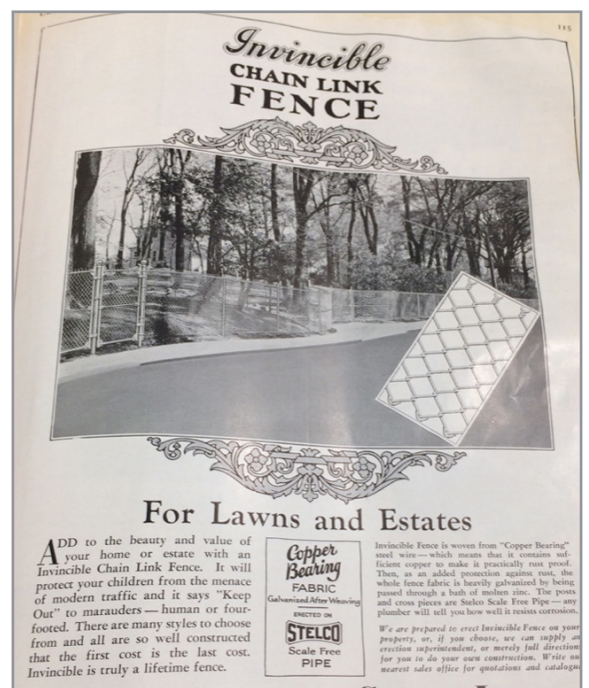

The Stehl Company of Cavada, Livitei

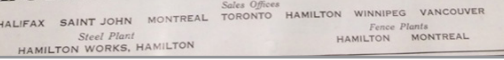

FIG. 7. "INVINCIBLE CHAIN LINK FENCE," THE STEEL COMPANY OF CANADA LIMITED, MARCH 1930, P.115 | CANADIAN HOMES \& GARDENS

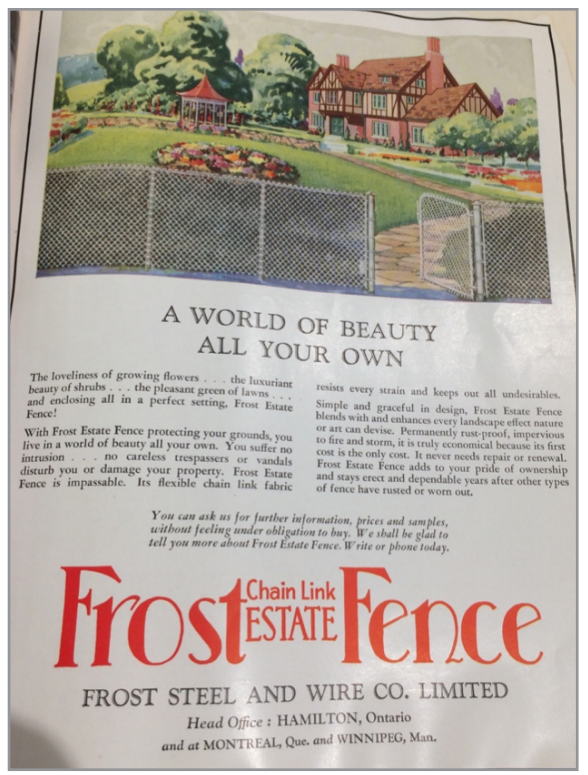

FIG. 9. FROST FENCE ADVERTISEMENT, MAY 1930, P.77| CANADIAN HOMES \& GARDENS

property, manifested by fencing one's yard and confining a lawn to the use of a single-family unit. While lawns, especially front lawns, functioned at least in part as a display of wealth, labour and taste, fences ensured that the public audience

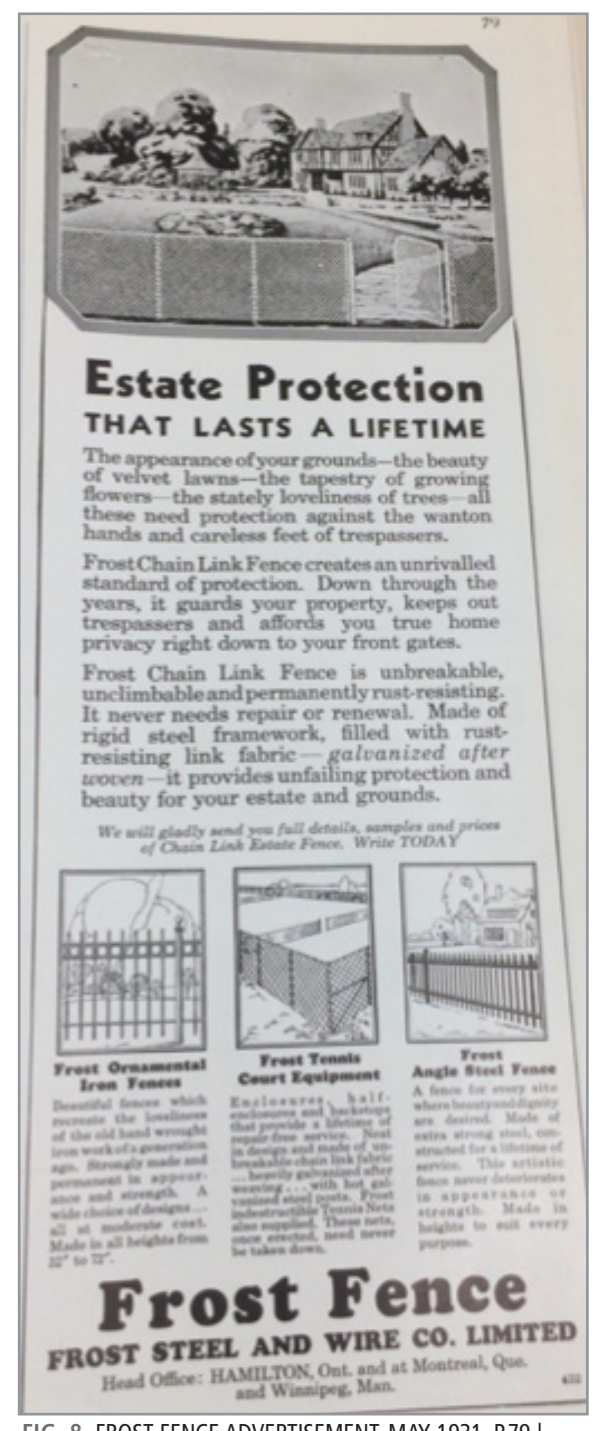

FIG. 8. FROST FENCE ADVERTISEMENT, MAY 1931, P.79 | CANADIAN HOMES \& GARDENS

of those images did not trespass onto the object of their gaze. The American landscape architect Frank A. Waugh, in 1939, suggested that fences "answer a want keen and urgent in the ordinary homeowner's heart: that is, to the desire for seclusion and privacy and the unmolested and unobserved enjoyment of the home owner's surroundings." 48 Fences, in these advertisements, become additional walls, sequestering private property and providing fortifications for seclusion and security. In this way, the lawn again functions as a room in one's home, separating one's belongings as well as one's life from those of others.

Advertisements for lawn fencing echo these desires: the chain link fences advertised by the Steel Company of Canada offer to "protect your children from the menace of modern traffic" and say "'Keep Out' to marauders," while Frost Chain Link Fences advertise a similar standard of protection for "velvet lawns" against "the wanton hands and careless feet of trespassers" (figs. 7-8). ${ }^{49}$ In a 1932 advertisement also run by Frost, a conversation between two women neighbours is staged through a chain link fence: one woman complains that she was formerly "so bothered by trespassers," feeling that her "grounds were never [her] own" due to "careless" feet, and the security that the "beautiful, permanent fence" makes the woman feel that the grounds are now "truly a part of [her] home." 50 Yet another advertises the ability of fences to protect their property-"a world of beauty all your own" illustrated by an expansive lawn with gazebo, garden and orchardfrom "careless trespassers or vandals" and "all undesirables" (fig. 9).

It is clear from the profusion of advertisements for lawn fences that the ownership of land, and the notions of privacy and separation which the enclosing of that land entailed, were central to the discourse around lawns in the magazine. Simultaneously, the lawn was a public arena for the demonstration of immaculate landscaping and laborious upkeep, and was thus both offered to neighbours as a display acting as visible proof of homeowners' taste and ability, and kept secluded for the private use of a singlefamily unit. The chain-link fences in the Frost advertisements might be seen to mediate between these functions; both 




FIG. 10. SMART'S LAWN MOWERS ADVERTISEMENT, APRIL 1932, P.54 | CANADIAN HOMES \& GARDENS

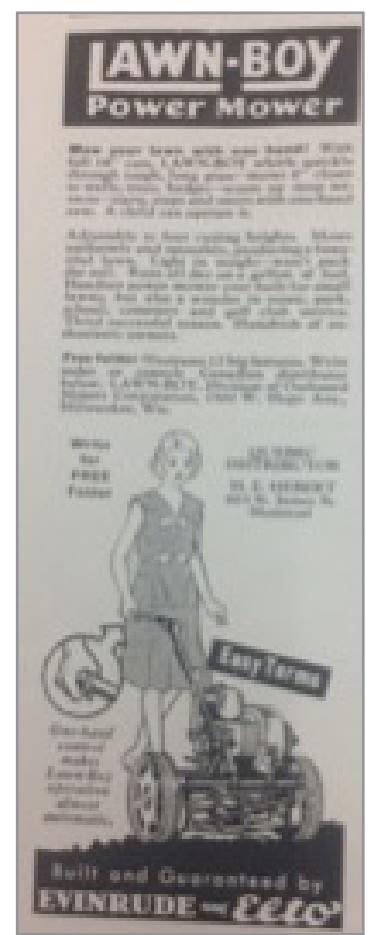

FIG. 11. LAWN-BOY POWER MOWER ADVERTISEMENT, MAY 1934, P.66 | CANADIAN HOMES \& GARDENS

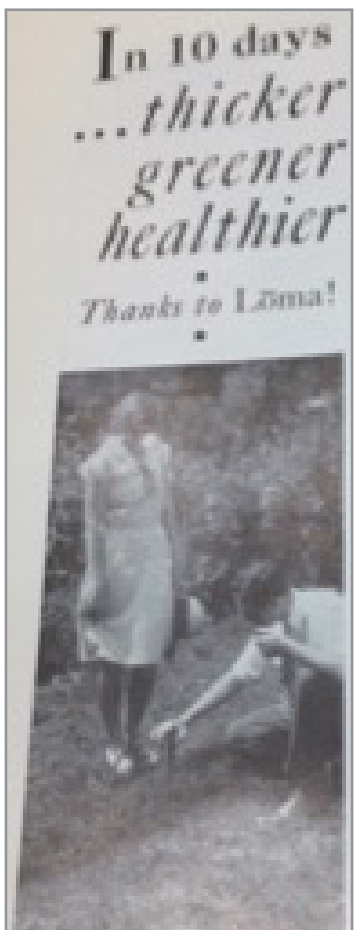

FIG. 12. LOMA ADVERTISEMENT, MAY 1931, P.100 | CANADIAN HOMES \& GARDENS

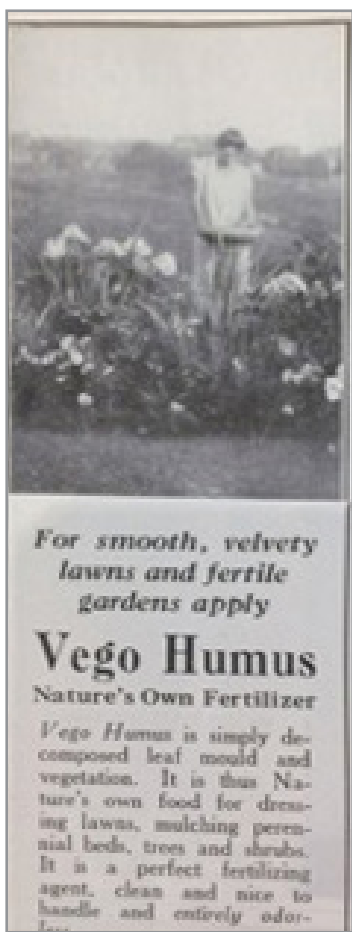

FIG. 13. VEGO HUMUS ADVERTISE MENT, JUNE 1926, P.90 | CANADIAN HOMES \& GARDENS assuring privacy by physically demarcating boundaries, yet maintaining visibility since their materiality ensures that they can still be seen through.

\section{CONQUERED GEOGRAPHY}

One of Lewis's axioms, that of "environmental control," points to the concept that many examples of "landscape" may be understood as "conquered geography"-thus, that we can understand the significance of landscapes by examining what humans have done to them. ${ }^{51}$ Lawns, by their nature, are artificial in that they only maintain their "emerald splendor" when subjected to "continual amputation" as well as chemical aid. ${ }^{52}$ It is conducive, then, to approach the lawn asking about each force that people enacted upon them in order to create an ideal. Here, a well-clipped and bright green lawn came to bespeak "a control over nature," and the upholding of residential suburbs, intended to serve as a "pastoral, idyllic setting appropriate for tender women and children" became an issue of morality. ${ }^{53}$ Advertising lawn care to men, Virginia Scott Jenkins has suggested, often exploited their fantasies of "control of the land," as they were told that "a good lawn is evidence of good citizenship" since it illustrated their ability to alter and control their land and thus provide for their families. ${ }^{54}$ This aspect of control was thus highly moralized through appeals to patriotism and masculinity. By the 1920s in Canada, three main instruments were at play in the project of maintaining the clearing: the lawn mower (which often included a lawn roller), fertilizers, and pesticides. Each is invoked in the magazine, in advertisements, advice columns, and article-length descriptions of homes and gardens, and each portrayal has gendered undertones.
One site for investigating the conceptions of gender at play on the lawn in the publication are its advertisements for lawn mowers. Of 58 advertisements for mowers surveyed, 38 simply featured an illustration of the mower itself, many of those atop a depiction of a well-trimmed lawn. Thirteen advertisements featured men pushing the lawnmowers, while two showed women completing the task, and five featured children. It appears, however, that mowing lawns was generally understood as a masculine task, since though the figures pushing the lawnmowers vary, the language of advertisements that featured only a mower most often reflected this gendered division of labour. ${ }^{55}$ A May 1926 advertisement for the Ideal "Power Mower" claimed that with the device, "one man" could "do the work of five men," and that "any unskilled man" could operate it. ${ }^{56}$ Many of the advertisements focus on the 
labour-saving capacity of mowers, which might contextualize the fact that some depict women or children mowing. An advertisement for Smart's Lawn Mowers, variants of which appeared throughout the late 1920s and early 1930s, features a young girl pushing an aluminum mower across a green lawn, accompanied by a running dog and wearing a nonchalant smile (fig. 10). Many of these advertisements, despite featuring illustrations of a child, are clear in their accompanying text that the device makes it easy for "a man" to mow "50\% more lawn per day." Seemingly in the same vein, a 1934 advertisement for the Lawn-Boy "Power Mower" features an illustration of a woman wearing a knee-length dress decorated with bows and pushing the device with one hand (fig. 11). This advertisement claims that "a child can operate it," and that operating it is so easy it is "almost automatic." It does not, however, explicitly suggest that a man might be doing the mowing, and the ease of control with which the woman featured handles it seems to suggest that the task would be open to women as well. Though advertisements featuring women make up a minority of those for mowers, their presence suggests that mowing the lawn was a contestable practice, not always aligned with masculinity.

Advertisements also frequently make a visual and linguistic association between lawncare and the act of shaving one's face. ${ }^{57}$ An April 1931 advertisement for the Smart mower emphasizes the "smoothness" and "razor-like keenness" of the aluminum machine, a quality amplified by the silver sheen of the full-page advertisement itself. ${ }^{58}$ An image of a home set back against a closely cropped front lawn accompanies the metallic motor. Other Smart advertisements emphasize the "keen-ness" of the mow and the "smooth, even" result, such as a run from
April 1930, and one from May 1930 points to the "keenest cutting blades, of the finest steel" able to make "smart lawns-cut evenly without a blemish." ${ }^{59}$ A 1933 run for a Monarch mower similarly emphasizes the accuracy and "close cutting" that the tools perform. ${ }^{60}$ This constitutes a subtle mode through which lawncare could be coded as a masculine task, but further, it is a clear connection between well-kept lawns and a metaphor of hygiene. Anne McClintock has stated that the organization and cleanliness of private space was instrumental in notions of domesticity that worked as part of the civilizing force of "the colonial enterprise." ${ }^{61}$ When domesticity was implicated in projects that extended beyond the home, it was often through its maintenance of a clean, and thus civilized, home front.

Another standard for lawncare that became "increasingly critical" in the interwar period was the expectation that one fertilized their lawn regularly. ${ }^{62} \mathrm{~A}$ majority of the advertisements for fertilizer featured in Canadian Homes \& Gardens draw an association between the fertilizer product and food, suggesting an association with domesticity, caregiving, and good health. More than half of the advertisements featured throughout the magazine feature a fertilizing product manufactured by Canadian Industries Limited, called both "Gro-More" and "Plant Food." 63 These advertisements consistently invoke concepts of "nutrients" and the idea of "feeding" the lawn. ${ }^{64}$ Vigoro advertisements similarly characterize the product as a "square meal" for lawns and flowers. ${ }^{65}$ This is a gendered notion, as women's role as caregivers and nurturers has been an indispensable ideology for organizations that emphasized women's role in advancing the Canadian nation. ${ }^{66}$ Women often appear in advertisements for fertilizers-either alone, as in a June 1926 advertisement for Vego Humus, or accompanied by a man, as in a 1931 advertisement for Loma (figs. 12-13). In both, women in white dresses stand surrounded by lawns and gardens, surveying their growth, while, in the Loma advertisement, the man stoops to measure the growth of the grass. A Vigoro advertisement from April 1934 also prescribes a "square meal" for "half-starved" lawns, here, a "master gardener," an unnamed man in glasses, is the authority for the advice, suggesting that "incomplete ration[s]" are not sufficient for proper lawn upkeep. ${ }^{67}$ Thus, while women most often appear in advertisements for fertilizer, men are also featured as experts on lawn health; women and men, alternately, are implicated in that task. ${ }^{68}$

In advertisements for pesticides, which began to proliferate throughout advertisements in the 1920s, when weed-free lawns became the standard, gendered imagery is also apparent. ${ }^{69}$ The insecticide "The Evergreen," manufactured by McLaughlin Gormley King Co., consistently depicts its product using a mascot figure of a cartoon uniformed soldier, dubbed "the Garden Cop."70 That "Cop" often appears spraying an illustrated stream of insecticide which is overlaid onto photographs of gardens or lawns. ${ }^{71}$ In one case, the "Garden Cop" is featured as part of a small group of other uniformed figures, evoking an army. ${ }^{72}$ A figure of regulation, this personification was intended to illustrate the way that the product kept lawns free of unwanted weeds using force: the character appears to deploy the pesticide as though it were a weapon. The personification of the active and forceful agent as a masculine figure and the description of gardens using language such as "tender" work together to conjure an image of a pure environment that must be kept free of intruders. A moralized nationalism might be at play here, one perhaps 
only increased by the depiction of the "Cop" figure as white. ${ }^{73}$ One pesticide advertisement, which ran twice in 1930 for the product "Black Leaf 40," features a woman figure. In the image, which cautions readers to "safeguard" their flowers lest they be "robbed" of their "beauty and attractiveness," a woman dressed in a loose knee-length dress and high heels is depicted kneeling before a flowerbed, spraying it with a steady fan of the substance (fig. 14). The figure is rendered in a more realistic manner than that of the "Cop," and her stance and expression are gentler, though her intent is the same. Protecting the lawn and garden from insects is thus advertised with images that evoke both feminine caregiving and masculine defence, and the fact that pest control was presented as both a masculine and feminine task suggests its contestability as a gendered assignment.

\section{CONSUMERISM}

One of the purposes of the magazine was its function as a guide for consumers, a role clear in that the last twenty pages of every issue are almost entirely devoted to "directories." These were split into subsections: "Shrubs - Bulbs Plants" included retailers of seeds and plants as well as advertisements for the services of professional landscape designers, "Antiques, Decorations and Fine Arts" entailed furniture retailers, art galleries, and upholsterers, and "Smart Shops" listed hairdressers, beauty parlours, hat designers, millineries, gift shops, and an educational directory including profiles on boys' summer camps and girls' summer schools. Advertisements for boys' summer camps often reflected attitudes about the moralizing quality that nature could have for young men.

In part, we must understand the publication in the context of the mass consumer

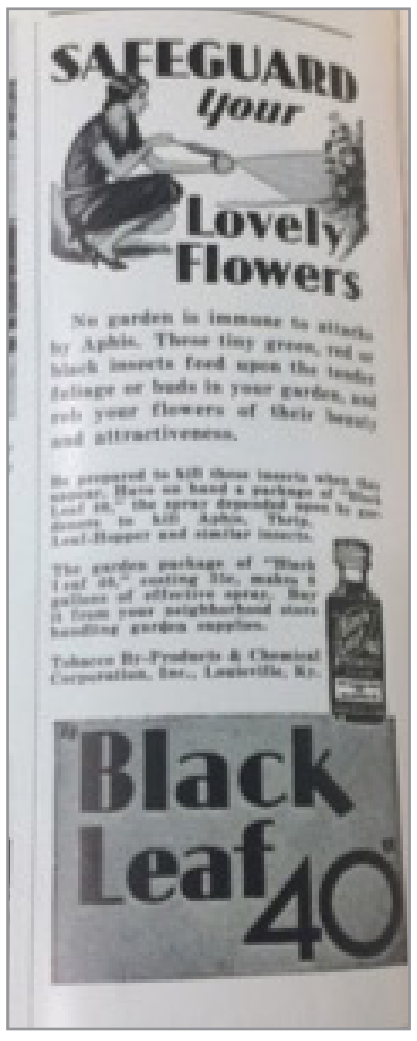

culture that had arisen by the 1920s, with consumption increasingly "a woman's responsibility." 74 As historian Cynthia Wright has identified, women's magazines (many of which were founded in the 1920s) and department stores were intimately linked as of the interwar period, with magazines "defining taste" while simultaneously identifying which department stores could cater to that taste. ${ }^{75}$ Among the pages of Canadian Homes \& Gardens, advertisements often appeared alongside articles and features with little distinction between types of content. This is distinctive of a magazine which largely concerned itself with advising readers on what to buy, often listing trends in homeware alongside text that suggested retailers that would carry such items. The magazine often framed women as the primary consumers of household decoration. Historian Graham Broad suggests that, in times of

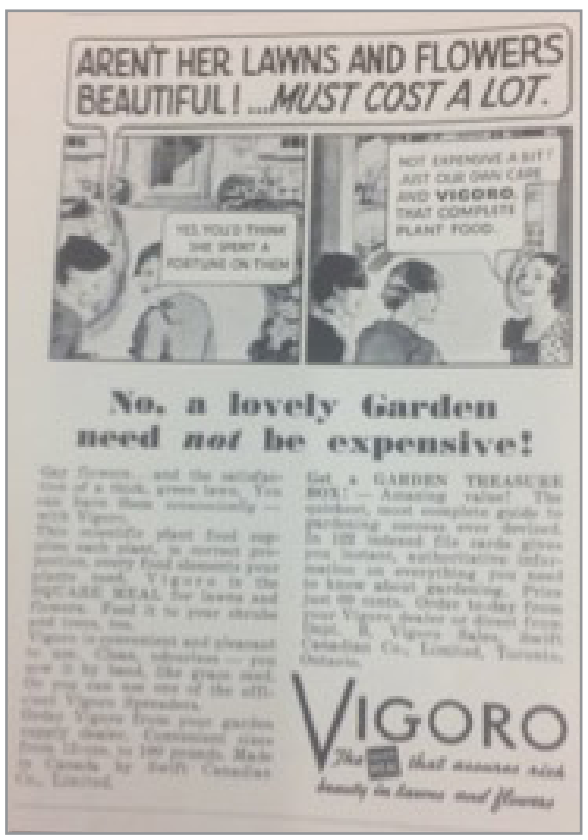

FIG. 15.VIGORO ADVERTISEMENT, MAY 1934, P.64 | CANADIAN HOMES \& GARDENS

FIG. 14. BLACK LEAF 40 INSECTICIDE ADVERTISEMENT, AUGUST 1930, P.94 | CANADIAN HOMES \& GARDENS

economic stress, women's consumption was understood through the concept of "patriotic consumerism," constituting a "fuller and more active public citizenship" for a population that was less often in the public sphere. ${ }^{76}$

Broad further suggests that most women's magazines, by the 1930s, assumed that women "were responsible for eighty-five cents of every consumer dollar spent in Canada," and this trend is often apparent in the magazine. ${ }^{77}$ Many advertisements appear to generally assume that women were the primary readers and consumers, directly targeting their demographic by invoking women's "natural" responsibility to cultivate discriminating taste. A 1931 advertisement, prepared by the "Advertising Agencies" in collaboration with some of the major Canadian magazines of the time, asks "why does a woman buy the brand?," suggesting women's 
proclivity for "keen" buying and understanding of quality. The advertisement depicts a woman using the telephone, as though she is researching products before procuring them. ${ }^{78}$ Other advertisements, such as a 1927 one for an ironer, emphasizes women's ability to influence the buying decisions of their husbands: "he does not know" how much of your labour the device will save, the advertisement tells women, and if you simply remedy his ignorance by showing him how much labour you do, he might buy the product. ${ }^{79}$ Women's position as either the sole buyers of a household or at least strong influences on buying decisions is solidified throughout the magazine.

A fertilizer advertisement from May 1934 appears to suggest women's responsibility, financial and otherwise, to keep "lawns and flowers" in good shape, and to solidify the idea that landscaping around the home is, at least in part, for public view. The advertisement features two panels, the first of which shows two women before an entranceway, admiring the beautiful "lawns and flowers" on the property and speculating that the woman living there must have spent a "fortune" to keep them that way. In the second panel, the woman responsible for that well-maintained property replies that it has not at all been expensive, endorsing the fertilizer (fig. 15). Here, a successfully cultivated lawn is associated with the financial sensibility and good taste of a woman who is able to make practical economic choices that also enhance the beauty of her home. It is clear therefore that the woman in the advertisement has made a purchasing decision that has been beneficial to her home, and that she feels pride in her role as household consumer and her success in a semi-public realmher skill in homemaking visible to other women as well as to her own husband.
Lawns, then, could be avenues by which women exercised agency; it was their purchases that ensured a successful lawn, their homemaking skills that made it look inviting, and even their labour that went into cultivating the gardens framed by their grass, though the expectation of lawncare itself was generally reserved for men. Drawing from historian Heather Murray's work on Canadian women pioneers, the outdoor space surrounding the home-the "pseudo-wilderness"-might be understood as a "marginal, middle ground" wherein women could "negotiate sociocultural values and gender roles." 80 Indeed, Ponte suggests that as gardening was increasingly thought of as a respectable occupation for women, a connection explicitly clear in the era from 1900-1930, when books on gardening for women were printed in unprecedented numbers, that association was increasingly accompanied by "covert or explicit feminism." ${ }^{81}$ Ward notes that some have suggested that "the path to women's empowerment passed through the garden," so the lawn could act as an avenue through which women's work might cross the threshold from interior to exterior. ${ }^{82}$

\section{CONCLUSION}

In 1931's "Summer Number" cover, the ambiguity of the lawn space is clear: the greenery is enclosed by a perimeter, interiorizing and privatizing it, but it also lies beyond a sheltered seating area, framed by the pillars of the home's architecture. Brightly hued grass resembling coloured carpeting and trendy furniture strewn with decorations bring the suggestion of the domestic living space, and one imagines a housewife tending to the cleaning of the patio, arranging furniture or tending to the flowers. The exteriority of the scene, however, suggests something else; not a real interior, and thus not entirely private, the yard is on display.
The trimmed hedges and sweeping, spotless lawn hint at a masculine control over the natural landscape, suggesting something else regarding the ambiguity of the space-its positionality as an area in flux.

Analyzing the mythology around the space of the lawn in Canadian Homes and Gardens can lend clarity to the way that outdoor domestic space was understood along the lines of gender in the interwar period in Canada. Not depicted as quite interior or exterior, upper-class Canadian lawns of that period functioned as a kind of liminal space, where both women and men were depicted and where they were both expected to participate, in occasionally overlapping and contradictory roles. The white nuclear family was often connected visually to the space of the lawn in Canadian Homes \& Gardens, so the aesthetic space exercised discursive power as a site of normativity. The exact gendered division of labour, and thus the gendered nature of the space, however, was often unclear: lawncare was assigned to both men and women in advertisements and articles, and as a space of leisure, the lawn could be a site for masculine dominance over the land as well as for family bonding and homemaking. As a space, the lawn was often articulated as almost part of the home's interior, simply another extension of domestic space come the ideal weather, but was not exactly private since it was essentially on display to neighbours and those who drove by as an emblem of the homeowners' ability to cultivate their property. Its existence was an in-between space, occupying the liminal space between public and private, labour and leisure, and male and female.

Because the readership of Canadian Homes \& Gardens was so limited by class, however, conclusions drawn from an analysis of the source material in this publication may only speak to the images 
and discourse with which Canada's upper class was presented. The case may be made that certain trends and aesthetics were echoed by the populations falling under lower-class categories after the trends set by elites, but ultimately, since the democratization of suburban lawn ownership was largely a postwar phenomenon, that argument is only likely to apply to Canada's middle-class lawns in the 1950s and 1960s. The visual trove offered in this publication is unique in the variety and detail of images of lawns, but can only speak to the reality of upperclass Canadians living in large singlefamily homes.

Looking at popular articulations of architectural space is valuable because illustrations in widely disseminated publications envision how spaces were ideally experienced. Architectural history discourse has engaged at length with the division between the public and private and with the gendered associations implicated in these divisions. This paper has shown how these mythologies function on the microcosmic level of a network of individual images of a space that has been classified as belonging, paradoxically, to both categories. While the scope of this paper is necessarily limited by the necessity of engaging at length with a multitude of individual images, a detailed examination of the vast array of lawn imagery throughout all the publications in this temporal span could aspire to a fulsome picture of the contradictory and layered concepts surrounding the imagery involved in constructing the mythologies of gender and the space of the lawn in the interwar period.

\section{NOTES}

1. Wright, Cynthia, 1992, "'Feminine Trifles of Vast Importance': Writing Gender into the History of Consumption," in Franca lacovetta and Mariana Valverde (eds.), Gender Conflicts: New Essays in Women's History, Toronto, University of Toronto Press, p. 245.

2. Jackson, Kenneth T., 1985, Crabgrass Frontier: The Suburbanization of the United States, Oxford, Oxford University Press, p. 11. Because this research overlaps with the 1929 stock market crash, it is telling that there is little change in the tone or content of the articles and advertisements between the late 1920 s and the early 1930s. It is likely that the audience of this magazine was generally wealthy enough to avoid the worst financial effects of the Depression, since the magazine still recommends regular changes in home decoration, expensive home additions, and luxury real estate listings. The economic downturn was most directly invoked, however, in advertisements for glass greenhouse addons. These encouraged Canadians to "increase [their] means of hospitality and social scope," insisted that "Canada is the best place on the globe in which to live today," and called to the readership to "overcome the depression of today," rallying them to "come out boldly and SPEND ... spend HARD" (Lord \& Burnham, 1931, "SPEND," Canadian Homes \& Gardens, vol. 8, March, p. 44-45). Another, in October 1931, insisted that adding a conservatory would "be helping to overcome the current depression by setting money in circulation" (Lord \& Burnham, 1931, "The Addition," Canadian Homes \& Gardens, vol. 8, October, p. 37). A third, in 1932, insisted "depressions of one kind or another are nothing new," suggesting that Canada's "lack of confidence" was "deplorable" and that it would easily overcome the situation because of its "sound traditions and strong inter-empire bonds (Lord \& Burnham, 1932, "O Tempora!" Canadian Homes \& Gardens, vol. 9, August, p. 17). Conservatories had dropped in price by 1932, and readers were encouraged to "build for enjoyment ... and to give employment" (Lord \& Burnham, 1932, "Now-with Prices the Lowest," Canadian Homes \& Gardens, vol. 9, July, p. 33). The readers of the magazine, then, were appealed to solve the Depression; they were assumed to be those with means who could reinvigorate the economy by investing money in it and providing employment for the working classes.
3. Edwardson, Ryan, 2008, Canadian Content: Culture and the Quest for Nationhood, Toronto, University of Toronto Press, p. 102.

4. Korinek, Valerie J., 2000, Roughing it in the Suburbs: Reading Chatelaine Magazine in the Fifties and Sixties, Toronto, University of Toronto Press, p. 20-23.

5. Jenkins, Valerie S., 1994, The Lawn: A History of an American Obsession, Washington, Smithsonian Books.

6. Wigley, Marc, 1999, "The Electric Lawn," in Georges Teyssot (ed.), The American Lawn, Princeton and Montreal, Princeton Architectural Press with the Canadian Centre for Architecture, p. 156.

7. Ward, Peter, 1999, A History of Domestic Space: Privacy and the Canadian Home, Vancouver, University of British Columbia Press, p. 150.

8. Id., p. 37.

9. Lewis, Pierce F., 1979, "Axioms for reading the Landscape: Some Guides to the American Scene," in Donald W. Meinig (ed.), The Interpretation of Ordinary Landscape: Geographic Essays, Oxford, Oxford University Press, p. 12.

10. Id., p. 15.

11. Id., p. 23.

12. Bower, Cayley, 2019, "Persistent Romance: Landscape, Canadianness, and Kingston's Catarqui Cemetery, 1850-1900," Journal of Canadian Studies, vol. 52, no. 3, p. 790.

13. Jenkins, The Lawn, op. cit., p. 14.

14. Jackson, Crabgrass Frontier, op. cit., p. 13.

15. Id., p. 4.

16. Ward, A History of Domestic Space, op. cit. p. 47.

17. 1926, Pyrene fire retardant advertisement, Canadian Homes \& Gardens, vol. 3, March, p. 104.

18. 1935, Chateau Cheese advertisement, Canadian Homes \& Gardens, vol. 12, June-July, p. 72.

19. 1932, Cine-Kodak advertisement, Canadian Homes \& Gardens, vol. 9, September, p. 39. All three of these advertisements were printed in colour, so their mythology is further enforced by the bright green colour of a well-cared-for lawn. 
20. Boyd, Shelley, 2009, "'Transplanted into Our Gardens': Susanna Moodie and Catherine Parr Traill," Essays on Canadian Writing, vol. 84, p. 35-58.

21. Bower, "Persistent Romance: Landscape, Canadianness," op. cit., p. 786.

22. Culham, Gordon, 1930, "English Garden Styles," Canadian Homes \& Gardens, vol. 7, July, p. 39-41.

23. Andrighetti, Rick, 1994, "Facing the Land: Landscape Design in Canada," Canadian Architect, vol. 39, no. 8, p. 14-15.

24. Culham, "English Garden Styles," op. cit., p. 41; Macpherson, Mary-Etta, 1930, "The Frost Performs its Secret Ministry," Canadian Homes \& Gardens, vol. 7, January, p. 17.

25. 1930, McDonald's Evergreen Lawn Grass Mixture advertisement, Canadian Homes \& Gardens, March, p. 92.

26. Ward, A History of Domestic Space, op. cit., p. 147.

27. 1931, "To Him Who has Been Long in City Pent," Canadian Homes \& Gardens, vol. 8, July, p. 3.

28. Quoted in Teyssot (ed.), 1999, The American Lawn, op. cit., p. 10.

29. Frost, Joe L. and Sue Clark Wortham, 1988, "The Evolution of American Playgrounds," Young Children, vol. 43, p. 21.

30. Frost Steel and Wire Co., Limited, 1927, "Frost O-Boy Home Playground Equipment," Canadian Homes \& Gardens, vol. 7, June p. 97. References to "healthful" and "health-giving" sunlight are similarly common in advertisements for glass greenhouse additions, which suggest that the glass rooms will provide families with enough "rays" to remain healthy and energetic throughout the winter. Advertisements for greenhouse lean-tos appear in every issue of Canadian Homes and Gardens-every issue features at least one, and those published in the winter months often include two or three.

31. Meredith, R. Brian, 1930, "Lakeside Farm," Canadian Homes \& Gardens, vol. 7, May, p. 24-25.

32. Macpherson, Mary-Etta, 1930, "The Business Man Turns to Farming," Canadian Homes \& Gardens, vol. 7, p. 30-33.

33. Kerber, Linda K., 1988, "Separate Spheres, Female Worlds, Women's Place: The Rhetoric of Women's History," The Journal of American History, vol. 75, no.1, p. 11.
34. 1933, "The Garden: An Intimate Extension of the House," Canadian Homes \& Gardens, vol. 9, July, p. 16; Langely and Howland, 1933, "Garden and Home Intimately Linked," Canadian Homes \& Gardens, vol. 10, August, p. 25.

35. The phrase "outdoor living room" appeared a total of 31 times across advertisements, articles, and native advertisements (normally in the form of articles) across 100 issues.

36. Kerber, "Separate Spheres, Female Worlds, Women's Place," op. cit., p. 32.

37. The Robert Simpson Company Limited, 1934, "Sun and Shade Furniture..." Canadian Homes \& Gardens, vol. 11, June-July, p. 12.

38. Jenkins, The Lawn, op. cit., p. 27.

39. Altree-Coley, G.E., 1932, "Garden Settings for Meals," Canadian Homes \& Gardens, vol. 9, June, p. 18-19.

40. A 1932 article by Helen G. Campbell, the then-director of the Chatelaine Institute, titled "Summer Drinks in the Perfect Setting," points to the importance of demonstrating one's "hospitality" toward "weatherworn guests," providing thorough instructions for serving cocktails, soda, and tea "at a moment's notice." Campbell, Helen G., 1932, "Summer Drinks in the Perfect Setting," Canadian Homes and Gardens, vol. 8, July, p. 27.

41. Ponte, Alessandra, 1999, "Professional Pastoral: The Writing on the Lawn, 18501950," in Teyssot (ed.), The American Lawn, op. cit., p. 95.

42. Teyssot, id., p. 5; Cleaveland, Henry W., William Backus, and Samuel D. Backus, 1856, Village and Farm Cottages: The Requirements of American Village Homes, New York, D. Appleton and Company.

43. Ideal Power Lawn Mowers, 1927, "An Ideal Power Mower Quickly Pays for Itself," Canadian Homes \& Gardens, vol. 4, February, p. 94.

44. Jenkins, The Lawn, op. cit., p. 81; Mills, John, 1983, "The Coming of the Carpet to the West," in Donald King and David Sylvester (ed.), The Eastern Carpet in the Western World: From the $15^{\text {th }}$ to the $17^{\text {th }}$ Century, Howard Gallery, London, Arts Council of Great Britain, p. 22.
45. Articles such as a March 1926 segment called "The Romance of the Oriental Rug" were common; these usually seemed in the business of "taste making," spotlighting certain patterns when they came into fashion, but they also often mentioned the methods of weaving especially as they differed from Western cultures. In this particular article, a long description of "Mahometan" prayer practice, housing, and payment is also included, suggesting an interest in the apparent "otherness" of their origin, which likely added to consumer's appreciation of the "romance" or luxury of the product (Babayan, Levon, 1926, "The Romance of the Oriental Rug," Canadian Homes \& Gardens, vol. 3, March, p. 43) Canadian Homes \& Gardens also occasionally included full-page colour advertisements for Persian rugs. The author of that article in particular was an oriental rug retailer in Toronto.

46. 1930, "The Backyard Garden Steps Out," Canadian Homes \& Gardens, vol. 7, January, p. 62.

47. Altree-Coley, G.E., 1930, "A Little Garden of Dreams," Canadian Homes \& Gardens vol. 7, February, p. 32-35.

48. Quoted in Teyssot (ed.), The American Lawn, op. cit., p. 19.

49. The majority of advertisements for lawn fences were for chain link or steel and iron fences, not for wood picket fences. According to Philip Dole, the preference for white picket fences grew out of an aesthetic appreciation for "the great European estates," presumably those dating prior to the eighteenth century, but Dole's investigation of their adaptation in North America largely cites examples from the mid-twentieth century (p. 28). The initial rise of chain link fences, according to Gregory Dreicer, was tied to military uses as well as "an army of new home owners" in the early twentieth century. Dreicer, Gregory K. (ed.), 1996, Between Fences, Washington, DC, National Building Museum, New York, Princeton Architectural Press, p. 81.

50. Frost Steel and Wire Co., Limited, 1932, "Now with Frost Fence my grounds are truly my own," Canadian Homes \& Gardens, vol. 8, May, p. 40.

51. Lewis, "Axioms for reading the Landscape," op. cit., p. 25.

52. Teyssot (ed.), The American Lawn, op. cit., p. 3.

53. Ward, A History of Domestic Space, op. cit., p. 148; Jenkins, The Lawn, op. cit., p. 20.

54. Jenkins, id., p. 118. 
55. Ted Steinberg states that mowing was "mostly a chore assigned to the boy in the family" (Steinberg, Ted, 2007, American Green: The Obsessive Quest for the Perfect Lawn, New York, W.W. Norton, p. 13). Jenkins notes that women were often advertised to for the purchase of lawn supplies, but that they were generally told to have their sons, husbands, or gardeners upkeep their lawns (Jenkins, The Lawn, op. cit., p. 118).

56. Ideal Power Lawn Mowers, 1926, "The Mower Paid for Itself in a Season," Canadian Homes \& Gardens, vol. 3, May, p. 96.

57. Frank J. Scott compared cutting the lawn to the operation of a face razor in 1870, and the landscape architect Fletcher Steele made the same connection in 1964. Teyssot (ed.), The American Lawn, op. cit., p. 6.

58. James Smart Plant, 1931, “Endurance Aluminium Lawn Mower," Canadian Homes \& Gardens, vol. 8, April, p. 68.

59. James Smart Plant, 1930, "Smart's Lawn Mowers," Canadian Homes \& Gardens, vol. 7, April, p. 85; James Smart Plant, 1930, "Smart's Mowers," Canadian Homes \& Gardens, vol. 7, May, p. 141.

60. Monarch Motor Mower, 1933, "Beautiful Lawns," Canadian Homes \& Gardens, vol. 10, July, p. 44.

61. Cited in Heynen, Hilde, 2005, "Modernity and Domesticity: Tensions and Contradictions," in Hilde Heynen and Gülsüm Baydar (eds.), Negotiating Domesticity: Spatial Productions of Gender in Modern Architecture, London, Routledge, p. 1-29 at p. 9.

62. Jenkins, The Lawn, op. cit., p. 86

63. Twenty advertisements for fertilizer were identified throughout the surveyed issues.

64. Canadian Industries Limited, 1930, "Gro-More Fertilizer," Canadian Homes \& Gardens, vol. 7, April, p. 134.

65. Vigoro, 1932, "You Can't Expect Real Beauty from a Half-starved Lawn," Canadian Homes \& Gardens, vol. 9, April, p. 66.

66. Snell, Rachel A., 2018, "God, Home, and Country': Women, Historical Memory, and National Identity in English Canada and the United States," American Review of Canadian Studies, vol. 48, no. 2, p. 253.

67. Vigoro, 1934, "Undernourishment Fades Lawns and Gardens," Canadian Homes \& Gardens, vol. 11, April, p. 71.
68. This advertisement might find echoes in the increasing professionalization of home economics and scientizing of traditionally women's tasks that was also developing during the interwar period.

69. Jenkins, The Lawn, op. cit., p. 85.

70. Both including and excluding advertisements run more than once, advertisements featuring the "Garden Cop" outnumber the pesticide advertisements that featured only an illustration of the product and practical information about its use. Counting advertisements that appear multiple times, the Garden Cop appears in 16 of 24 of those. Without reruns, the Garden Cop advertisements outnumber those with no personified characterizations by six to four.

71. McLaughlin Gormley King Co., 1930, "The Ever Green Non-poisonous Insecticide to Protect your Garden," Canadian Homes \& Gardens, vol. 7, June, p. 84

72. McLaughlin Gormley King Co., 1931, "The Ever Green Non-poisonous Insecticide," Canadian Homes \& Gardens, vol. 8, June, p. 104.

73. Beatriz Colomina has suggested that for Americans during the Second World War, the lawn was articulated as a "right" for families on the home front and thus as "a sign of postwar patriotism," who were encouraged to maintain their lawns so that their soldiers would be happy to return (Colomina, Beatriz, 1999, "The Lawn at War: 1941-1961," in Teyssot (ed.), The American Lawn, op. cit., p. 135, 149). Many of the images sent to the soldiers in the trenches of home featured lawns, so they functioned to signify an image of "home" for soldiers to ideologically defend (p. 135). She also points to the significance of Victory Gardens during the war, another instance in which properly-cared-for lawns were aligned directly with performative nationalism (p. 136).

74. Wright, "'Feminine Trifles of Vast Importance," op. cit., p. 231.

75. Id., p. 245.

76. Broad, Graham, 2013, A Small Price to Pay: Consumer Culture on the Canadian Home Front, 1939-45, Vancouver, University of British Columbia Press, p. 19.

77. Id., p. 17.
78. Pennel, Margaret, Advertising; Canadian Homes \& Gardens; Mayfair; Maclean's Magazine and The Chatelaine, 1931, "Why Does a Woman Buy the Brand?" Canadian Homes \& Gardens, vol. 8, August, p. 59.

79. Simplex Ironer, 1927, "Show your Husband!" Canadian Homes \& Gardens, vol. 4, February, p. 82.

80. Boyd, "Transplanted into Our Gardens," op. cit., p. 37

81. Ponte, "Professional Pastoral," op. cit., p. 96

82. Ward, A History of Domestic Space, op. cit., p. 152. 